\author{
UNIVERSIDADE DE SÃO PAULO \\ FACULDADE DE ODONTOLOGIA DE BAURU
}

MARIELE VERTUAN

The effect of $\mathrm{TiF}_{4}$ varnish after pre-treatment with MMP inhibitors on dentin erosion with or without demineralized organic matrix 



\section{MARIELE VERTUAN}

Efeito do verniz de $\mathrm{TiF}_{4}$ após tratamento inicial com inibidores de MMP na erosão da dentina com e sem matriz orgânica desmineralizada

The effect of $\mathrm{TiF}_{4}$ varnish after pre-treatment with MMP inhibitors on dentin erosion with or without demineralized organic matrix

Dissertação constituída por artigo apresentada a Faculdade de Odontologia de Bauru da Universidade de São Paulo para obtenção do título de Mestre em Ciências no Programa de Ciências Odontológicas Aplicadas, na área de concentração Dentística.

Orientador: Prof. Dr. Heitor Marques Honório

BAURU 
Vertuan, Mariele

The effect of $\mathrm{TiF}_{4}$ varnish after pre-treatment with MMP inhibitors on dentin erosion with or without demineralized organic matrix / Mariele Vertuan Bauru, 2019.

61 p. : il. ; $31 \mathrm{~cm}$.

Dissertação (Mestrado) - Faculdade de Odontologia de Bauru. Universidade de São Paulo

Orientador: Prof. Dr. Heitor Marques Honório

Autorizo, exclusivamente para fins acadêmicos e científicos, a reprodução total ou parcial desta dissertação por processos fotocopiadores e outros meios eletrônicos.

Assinatura:

Data: 
FOLHA DE APROVAÇÃO 



\section{DEDICATÓRIA}

Dedico este trabalho à Deus, sem o qual eu nunca conseguiria forças para realizar essa conquista e superar todos os obstáculos que a vida nos impõe.

Também dedico esta dissertação à pessoa mais importante da minha vida, a minha mãe, Maria Isabel Albertini Vertuan (in memorian). Mãe, já faz quase um ano que eu estou tendo que aprender a viver sem você aqui comigo e isso é extremamente difícil e doloroso. A vida ficou de ponta cabeça, a voz no telefone (todos os dias) não é mais a sua, a casa não é mais a mesma sem você, a melhor comida do dia não é a sua... O abraço, o beijo, o colo não são mais o seus. Sou obrigada a continuar a caminhada sem a engrenagem que movia meus motores, que me dava forças e orientação para superar qualquer mínima situação que me incomodasse. Você sempre foi minha direção, minha solução, meu calmante, aconchego, porto seguro. É como se, quando eu estivesse embalada pelos seus braços, nada pudesse me alcançar ali dentro. Tudo se resolvia em um beijo, ou em uma simples palavra de carinho e conforto. Agora... a vida anda um pouco enegrecida e tem a saudade como inquilina permanente, todos os dias, em cada tarefa que deve ser feita, em cada coisa legal que acontece, em cada "mãe" que eu encontro... Como eu queria a minha mãe aqui, meu maior amor, meu grude, amiga. Confesso que estou morrendo de saudade! Mas você sempre será meu exemplo e inspiração, de mulher, de mãe, de fé, de paciência, de agilidade e disposição. Passou por tantos desafios sem fraquejar e reclamar de um se quer... Eu tenho certeza que se estivesse aqui, estaria sentada na primeira fila de cadeiras desse anfiteatro... Como eu queria! Espero que você possa se orgulhar de mim - estou tentando "dar conta" dos estudos, da casa, das tias e, dessa teimosia, que é o pai. Que eu possa ser tão boa ou, pelo menos, um pouquinho do que você era para mim e para o mundo! Por favor, não saia do meu lado nunca, eu preciso muito de você! EU TE AMO, PARA SEMPRE! 

"Mãe é quem fica. Depois que todos vão. Depois que a luz apaga.

Mãe fica. Espremida no canto da cama durante a noite. Fica com o resto da comida do filho, fica preocupada se ainda não foi dormir.

Quando a gente fica que nasce a mãe. Na presença inteira. No olhar atento. Nos braços que embalam. No colo que acolhe.

Mãe é quem fica quando o chão some sob os pés. Quando todo mundo vai embora.

Quando as certezas se desfazem. Mãe fica.

Mãe é a teimosia do amor, que insiste em permanecer e ocupar todos os cantos. É caminho de cura. E no filho que vai, sempre fica um pouco da mãe.

No coração do filho, mãe fica."

Saudosa lembrança também deixo aqui, aos meus avós Tereza Marestoni e Armando Albertini (in memorian). Tenho certeza que vocês e minha mãe estão juntos novamente, olhando sempre por mim, pela "menina" de vocês! 



\section{AGRADECIMENTOS}

São tantas pessoas especiais que nos ajudam na caminhada dessa vida. Brevemente, vou descrever sobre pessoas sem as quais eu não poderia ter chegado até aqui.

Primeiramente, gostaria de agradecer ao meu pai, Antonio Carlos Vertuan. É incrível como somos iguais, com o mesmo temperamento, do mesmo jeito. A mãe era a engrenagem que nos movimentava em sincronia. Mas até que não estamos nos saindo tão mal assim. Obrigada, pai, por sempre fazer DE TUDO por mim! Eu não poderia ter um pai melhor nesse universo. Você cuida de mim a cada segundo! Tenho certeza que somos uma boa dupla! Obrigada por aguentar firme, por me ajudar a "colocar a mão na massa" e enfrentar de tudo ao meu lado. Não tem sido uma época fácil, nem boa, mas juntos vamos caminhando e nos apoiando, um no outro. EU TE AMO! E você é minha razão de viver. Obrigada por sempre se esforçar para me proporcionar tudo o que tenho hoje!

Gostaria de agradecer ao meu namorado, Caio. Você "chegou” já em uma época difícil, mas não me deixou. Esteve ao meu lado nos piores momentos da minha vida até hoje. Sempre cuidado de mim, me tratando com carinho e atenção. Você que me ajuda, dia após dia, a devolver os tijolinhos nos lugares. Um homem maravilhoso, com princípios e valores nobres. Obrigada por ser tudo que eu pedi à Deus, meu namorado, meu amigo, meu companheiro. EU TE AMO! Junto com você, eu também ganhei uma segunda família. Onde me senti amada e acolhida. Ganhei, também, vários presentes: dentre eles, uma segunda mãe, Shirley,tão maravilhosa... Muito obrigada por tudo o que você faz por mim, por sempre me escutar, orientar e cuidar com tanto amor e carinho!

Também não posso deixar de agradecer as minhas tias, Ema, Lucia, Cida, Jacinta e Clarice e ao meu tio Gerson, que cuidam de mim como uma filha! Obrigada por tudo! Eu amo muito vocês. São meus pedacinhos da Isabel ainda aqui. Agradecer a minha avó Amélia, que cuida do meu pai como se fosse seu neném ainda e também cuida de mim! Agradecer aos meus primos, que sempre estão ao meu lado: Angelita, Vanderléia, Leandro, Sérgio e Edinaldo.

Agradecer aos meus amigos, de uma maneira mais geral, que são amigos de verdade, sempre estiveram e estão ao meu lado, não importa a distância, o tempo, a situação... Eu sou muito grata por ter cada um de vocês, cada um sabe da importância e do amor que sinto, do espaço que ocupam em minha vida. São meus irmãos de alma e coração. Alyssa, Genine, Flávia, Karol, Bruno, Guto, Mariana, Rafael, Carol, Amanda, Vitor Lisboa, Ana Paula, Maiara, Marina, Maria Cláudia, Poliana, Isabela, Letícia, Marília, Orlando, Larissa, 

Juliana, João Pedro, Vinícius, Pedro, Mateus, João Gabriel, Victor, Carolina, Gerson... A minha turma do mestrado - Leandro, Naoki, Danielle, Francielly, Camila Queiroz, Edgar que fizeram a caminhada ser mais leve e alegre. Meu muito obrigada! Também aos amigos que foram conquistados durante a pós-graduação, vocês são especiais e eu os adoro muito: Ligia, Nathália, Murilo, Jefferson, Giovanna, Letícia, Marina, Fernanda, Ana Boteon, Mayara... À querida amiga, companheira, co-orientadora desde sempre, Beatriz, muito obrigada por sempre estar a disposição para me ajudar. Mesmo que seja o trabalho mais chato do universo ou o mais complicado, você sempre consegue dar o jeitinho "Bia" de deixar tudo perfeito. Muito obrigada mesmo, Bia, por me acompanhar desde o $1^{\circ}$ ano da graduação e ainda não ter cansado de mim! kkk Você é maravilhosa e uma amiga que quero ter para sempre em minha vida!

A todos os funcionários que nos ajudam no dia-a-dia, vocês são maravilhosos. Obrigada por tudo! Audria, Natália, Elísio, Rita, Nelson, Charlene, Alcides, Hebe, Thelma, Leila, Fátima, Letícia, Ivânia...

Gostaria de agradecer imensamente a todos os professores que me inspiram nessa caminhada. Vocês são exemplos. Eu sou muito grata à Deus por ter encontrado vocês, além de professores, são amigos, são carinhosos, zelosos e eu não tenho como agradecer, nem sequer demonstrar, o tanto que vocês são importantes para mim! A todos os professores que me apoiaram, me deram carinho e conforto quando a minha mãe faleceu, vocês não têm ideia de como me fazem bem... Meu muito obrigada, de todo coração. Se eu fosse falar de cada um de vocês aqui, daria para fazer um livro! Mas em especial, quero dizer meu MUITO OBRIGADA aos professores(as) Linda, Teresa, Juliana, Adilson, Sérgio, Bella, Rafael, Paulinho, Ana Flávia, Karin, Lucimar, Estevam, Pedro, Paulo, Dani Rios, Leonardo, Ivy, Eduardo Sanches, Mariana, Carla, Carol e Heitor.

Heitor, meu orientador durante o mestrado. Carol, minha orientadora durante a graduação e hoje minha co-orientadora. Nossa história já começou desde o vestibular da FUVEST, não é mesmo? Aposto que foi amor à primeira vista! Obrigada por serem pessoas tão abençoadas. Eu sou imensamente feliz de tê-los em minha vida, não poderia ter pessoas melhores para me orientar durante esses anos de pós-graduação. Heitor, eu adoro essa nossa dupla de bichados! Não teria como ter orientador melhor, que me entende, cuida de mim como filha, ensina e também puxa a orelha quando for necessário. Você deixa a vida da pós-graduação ser mais leve. Esse seu perfeito equilíbrio, sabendo que a vida não é só na universidade, mas que a família e aqueles que nos esperam em casa são mais importantes do que tudo, me deixou muito mais a vontade para conseguir cumprir com meus compromissos, sem paranoias, muito pelo contrário, com leveza e vontade. Obrigada por tudo! 

Eu não sei o que seria de mim na pós-graduação, principalmente, sem você! Eu te admiro muito! E eu te amo demais! Obrigada por sempre se preocupar comigo, se eu estou bem, acima de qualquer obrigação e tarefa da vida acadêmica. Cada vez eu tenho mais certeza de que quero ser como você! E que quero estar sempre junto de você! Obrigada, obrigada, obrigada! Carol, como falar que você não é maravilhosa? Eu rodo, rodo, rodo e sempre acabo caindo na Bioquímica... A verdade é que não tem mais como me separar de lá e você vai ter que me “aguentar"... Não posso deixar de falar que você nasceu para ser mãe! Sua eficiência, inteligência, perfeição e equilíbrio só cresceram em exponencial desde que as duas bonecas chegaram. Eu amo ver essa Carol mãe, professora, pesquisadora, super-herói, que sabe tudo de tudo e também que resolve tudo! Obrigada, de coração, por sempre me aceitar na sua sala, no laboratório, no grupo dos orientados da Bioquímica e nunca me abandonar! Quero poder sempre caminhar junto com você também!

Obrigada à Cristiane e a Lívia, por terem aceitado estar presentes na banca avaliadora dessa pesquisa de mestrado. Por, além de tudo, além da amizade, serem pessoas que eu tenho um carinho enorme, que me viram começar a iniciação cientifica, que sempre me ajudaram no laboratório e por quem eu tenho muita admiração! Sou muito feliz por ter vocês comigo.

Para finalizar, e não me estender muito mais, quero também agradecer a Coordenação de Aperfeiçoamento de Pessoal de Nível Superior - Brasil (CAPES) - Código de Financiamento 001 - pela possibilidade de realizar a pós-graduação com bolsa de estudos e por todo apoio durante os anos de Mestrado. 




\section{ABSTRACT \\ The effect of $\mathrm{TiF}_{4}$ varnish after pre-treatment with MMP inhibitors on dentin erosion with or without demineralized organic matrix}

This study tested the protective effect of $\mathrm{TiF}_{4}$ varnish, after pre-treatment with proanthocyanidin (PA) on the progression of erosive dentin wear, under the presence or absence of the demineralized organic matrix (DOM). For that, 360 bovine root dentin samples were polished and subjected to the analysis of the baseline profile. The samples were then eroded for 30 minutes ( $0.1 \%$ citric acid, $\mathrm{pH} 2.5)$ and the profile was measured again (erosion profile). Half of the samples were subjected to the DOM removal using collagenase for 4 days, while the other half remained immersed in water (with DOM). The removal of DOM was checked by profilometry (DOM profile). Samples were randomly divided into 24 groups $(n=15)$ according to the factors: 1 - With or without DOM; 2 - Pre-treatment with $0.012 \%$ chlorhexidine gel, $10 \%$ proanthocyanidin gel or untreated (control) for $1 \mathrm{~min} ; 3$ - Final Treatment with $\mathrm{TiF}_{4}$ varnish, $\mathrm{NaF}$ varnish, placebo varnish or untreated (control) for $6 \mathrm{~h}$. The samples were submitted to a $\mathrm{pH}$ cycling for 5 days: $0.1 \%$ citric acid $(4 \times 90 \mathrm{~s} /$ day) and immersion in artificial saliva between the challenges. The final profile was obtained for the calculation of dentin wear $(\mu \mathrm{m}$, three-way ANOVA/Tukey test). When DOM was preserved, the erosive wear was lower $(7.08 \mu \mathrm{m})$ compared to the condition without DOM $(9.80 \mu \mathrm{m})$, regardless of the treatments $(p=0.00)$. The pre-treatment had no influence on the amount of dentin wear $(p=0.63)$, while the final treatment was effective in reducing the progression of dentin wear (about 18\% compared to control, $\mathrm{p}=0.00)$. $\mathrm{TiF}_{4}$ was the only agent capable of reducing erosive dentin wear progression.

Key words: Dentin erosion. Fluoride varnish. Proanthocyanidin. 

RESUMO 



\section{RESUMO}

\section{Efeito do verniz de $\mathrm{TiF}_{4}$ após o tratamento inicial com inibidores de MMP na erosão da dentina com e sem matriz orgânica desmineralizada}

Este estudo teve por objetivo testar o efeito protetor do verniz de $\mathrm{TiF}_{4}$, após pré-tratamento com proantocianidina (PA) na progressão do desgaste erosivo da dentina, sob a presença ou ausência da matriz orgânica desmineralizada (DOM). Para isso, 360 amostras de dentina radicular bovina foram polidas e submetidas à análise do perfil baseline. As amostras foram então erodidas durante 30 minutos $(0,1 \%$ de ácido cítrico, $\mathrm{pH} 2,5)$ e o perfil foi novamente medido (perfil pós erosão). Metade das amostras foram submetidas à remoção do DOM usando colagenase por 4 dias, enquanto a outra metade permaneceu imersa em água (com DOM). A remoção do DOM foi verificada por perfilometria (perfil DOM). As amostras foram divididas aleatoriamente em 24 grupos $(n=15)$ de acordo com os fatores: 1 - Com ou sem DOM; 2 - Pré-tratamento com gel de clorexidina $0,012 \%$, gel de proantocianidina a $10 \%$ ou não tratado (controle) por $1 \mathrm{~min} ; 3$ Tratamento final com verniz $\mathrm{TiF}_{4}$, verniz $\mathrm{NaF}$, verniz placebo ou não tratado (controle) por $6 \mathrm{~h}$. As amostras foram submetidas a ciclagem de $\mathrm{pH}$ por 5 dias: $0,1 \%$ de ácido cítrico $(4 \times 90 \mathrm{~s} /$ dia $)$ e imersão em saliva artificial entre os desafios. O perfil final foi obtido para o cálculo do desgaste da dentina ( $\mu \mathrm{m}$, teste ANOVA de três fatores / Tukey). Quando a DOM foi preservada, o desgaste erosivo foi menor $(7,08 \mu \mathrm{m})$ em comparação com a condição sem DOM $(9,80 \mu \mathrm{m})$, independentemente dos tratamentos $(\mathrm{p}=0,00)$. O pré-tratamento não teve influência na perda de estrutura da dentina $(p=0,63)$, enquanto o tratamento final foi eficaz na redução da progressão do desgaste da dentina (cerca de 18\% comparado ao controle, $\mathrm{p}=0,00$ ). Porém, o $\mathrm{TiF}_{4}$ foi o único agente capaz de reduzir a progressão do desgaste erosivo da dentina.

Palavras-chaves: Erosão dentinária. Verniz Fluoretado. Proantocianidina 



\section{LIST OF ILLUSTRATIONS}

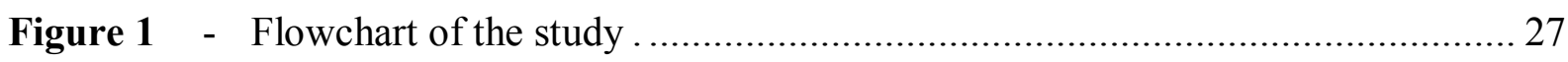





\section{LIST OF TABLES}

Table 1 - Mean values $( \pm \mathrm{SD})$ of dentin erosive wear $(\mu \mathrm{m})$ from samples submitted to the pre-treatmentes and final treatments in the presence or absence of DOM (non-contact laser profilometer). 



\section{TABLE OF CONTENTS}

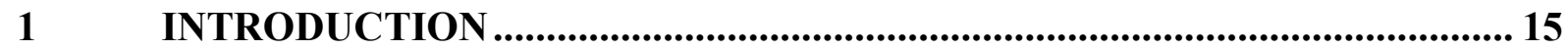

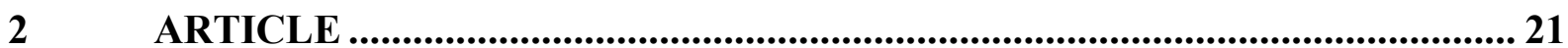

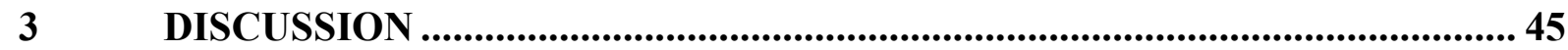

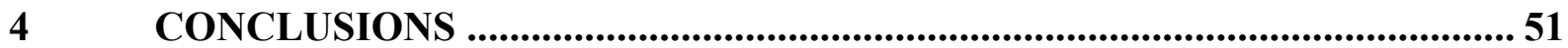

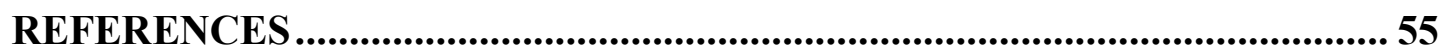



1 INTRODUCTION 



\section{INTRODUCTION}

Dentin has a high organic contente, consisting mainly of collagen fibrils (BUTLER, MUNKSGAARD, RICHARDSON, 1979; PASHLEY, 1991; HOULLÉ et al., 1997). Dental erosion is defined as the loss of tooth structure due to chemical process that does not involve bactéria (LUSSI, 2006; LUSSI, CARVALHO, 2014), which can affect the dentin when the enamel is lost or when there is radicular exposure. Studies indicate a high prevalence of tooth erosion in its early stages among adolescents (AGUIAR et al., 2014), with an estimated prevalence of $30.4 \%$ (SALAS et al., 2015a).

The decrease of $\mathrm{pH}$ in the presence of extrinsic and/or intrinsic acids induce to demineralization with organic matrix exposure as well as the activation of matrix metalloproteinases (MMPs), enzymes responsible for the degradation of extracellular matrix components during remodeling and degradation processes, which are present in the dentin itself and saliva. Subsequent neutralization by salivary buffers appears to increase the degradative activity of MMPs (TJÄDERHANE et al., 1998; MAZZONI et al., 2007; SULKALA et al., 2007; MAZZONI et al., 2011; KATO et al., 2011; SALAS et al. 2015b; FEMIANO et al., 2016).

The demineralized organic matrix (DOM) present at the lesion surface interferes with the diffusion of ions outside and inside the demineralized area, reducing the progression of erosion during subsequent acid attacks (GANSS, KLIMEK, STARCK, 2004). Therefore, collagen fibrils degradation by MMPs might speed up the progression of tooth erosive loss. It is expected that, clinically, erosive lesions have active degradation of the DOM by the action of proteases (SCHLUETER et al., 2012). The loss of the DOM might explain why tooth erosion seems to be harder clinically than that produced in the laboratory (GANSS, SCHULZE, SCHLUETER, 2013).

To minimize the erosive tooth loss, fluoride has been employed (WIEGAND, ATTIN, 2003; GANSS et al., 2010; MAGALHÃES et al., 2011; LUSSI, CARVALHO, 2015). The NaF mechanism of action is based on $\mathrm{CaF}_{2}$ precipitation on the tooth surface that would act as a mechanical barrier against acid and as a fluoride reservoir reducing demineralization and accelerating remineralization (GANSS et al., 2004; GANSS, SCHLUETER, KLIMEK, 2007; MAGALHÃES et al., 2011; FLURY et al., 2013; LUSSI, CARVALHO, 2015). However, 
besides the low acid resistance of the $\mathrm{CaF}_{2}$ globules, another limitation is the lack of protective effect on dentin when the DOM is enzymatically removed (GANSS et al., 2004; SCHLUETER et al., 2007).

On the other hand, fluoride containing polyvalent metals, such as $\mathrm{TiF}_{4}$, have shown a good efficacy against dental erosion (HOVE et al. 2006; MAGALHÃES et al. 2008; HOVE et al., 2008; MAGALHÃES et al., 2010; MAGALHÃES et al., 2011; LEVY et al., 2012; SOUZA et al., 2014; COMAR et al., 2015; CASTILHO et al., 2015; MAGALHÃES et al., 2016; MARTINES DE SOUZA et al., 2017). The better efficacy of $\mathrm{TiF}_{4}$, comparede to other fluoride salts, is due to the additional effect of titanium, which can minimize demineralization by interacting with the phosphate group to form a "glaze" layer over the surface (TEZEL, ERGUCU, ONAL, 2002; RIBEIRO, GIBSON, BARBOSA, 2006), rich in titanium phosphate dihydrate, titanium oxide and calcium fluoride (MAGALHÃES et al., 2013). In addition, it is suggest that $\mathrm{TiF}_{4}$ varnish interacts with the dental surface, due to the low $\mathrm{pH}$ of the agent, leading to an increase fluoride incorporation (GU, LI, SÖREMARK, 1996) as seen in the literature in one work involving enamel (COMAR et al., 2013).

MARTINES DE SOUZA et al. (2017) evaluated the effect of $\mathrm{TiF}_{4}$ varnish when applied in the presence or absence of DOM and show that this varnish obtained better results when compared to $\mathrm{NaF}$ varnish, especially when DOM was preserved, being superior to placebo and control varnishes (which did not differ statistically among themselves) (MARTINES DE SOUZA et al., 2017).

However, in order to preserve the DOM, several other studies have investigated the effect of enzyme inhibitors against tooth erosion (GENDRON et al., 1999; KATO et al., 2009; MAGALHÃES et al., 2009; KATO et al., 2010a; KATO et al., 2010b; KIM et al., 2011; KATO et al., 2012; KATO et al., 2014; BRACKETT et al., 2015). Inhibitors such as chlorhexidine (GENDRON et al., 1999; MAGALHÃES et al., 2009; KATO et al., 2010b; KIM et al., 2011) have shown excellent results in this process, but the search for natural protease inhibitors has attracted increasing attention (BEDRAN-RUSSO et al., 2008; BEDRAN-RUSSO et al., 2011; CASTELLAN et al., 2011; BEDRAN-RUSSO et al., 2014; SESEOGULLARI-DIRIHAN, 2015; BOTEON, 2017a; EPASINGHE, BURROW, YIU, 2017; NANDAKUMAR, NASIM, 2018). The main reasons for this are the lower toxicity of natural agents, minimal side effects, their characteristic of renewable/sustainable resource (BEDRAN-RUSSO et al., 2014) and less interaction with other products, such as MDP present in some adhesive systems (LIU et al., 2013). 
Among these natural agents, stands out the proanthocyanidin (PA), which is richly found in natural products such as cocoa, grapes, cranberry and peanuts (BEDRAN-RUSSO et al., 2014). Many studies have shown the inhibitory effect of MMPs on proanthocyanidin-rich agents, confirmed their dose-response effect and also that the PA provided less wear of the dentin submitted to erosive challenge (HAM et al., 2003; BEDRAN-RUSSO et al., 2008; RUEL et al., 2009; NAGPAL, MANUJA, PANDIT, 2013; BEDRAN-RUSSO et al., 2014; KHADDAM et al., 2014; LIU et al., 2014; BOTEON et al., 2017a; BOTEON et al., 2017b; SESEOGULLARI-DIRIHAN, 2015; EPASINGHE， BURROW， YIU， 2017; NANDAKUMAR, NASIM, 2018). Proanthocyanidin is considered a cross-linking agent, its effect has been attributed to its interaction with proline-rich proteins such as collagen (HIRAISHI et al., 2013) and has the ability to improve the mechanical properties of the dentin matrix by enhancing the bonds of the collagen fibrils and the bonds between them by inactivating the bonds with the MMPs (but although several cross-linking agents are available, their specific anti-MMPs are still unclear) (HIRAISHI et al., 2013; SESEOGULLARIDIRIHAN et al., 2016).

Therefore, the aim of this study was to compare the effect of $\mathrm{TiF}_{4}$ and $\mathrm{NaF}$, with equivalente fluoride concentrations, applied on pre-eroded dentin samples on reducing the progression of dentin erosive loss caused by an acid frequently found in the most known erosive beverages, when applied proanthocyanidin and chlorhexidine as inhibitors of MMPs, in order to preserv the demineralized organic matrix and to maximize the effect of the fluoride varnishes. Considering that clinically the DOM may be lost by enzymatic action, the results of the present study can guide clinical studies on preventive strategies to control dentin erosion.

This work tested the following null hypotheses: (1) there is no difference between the fluoride varnish on the progression of dentin erosion, regardless of the condition of the treatment and the presence or absence of the DOM; (2) there is no difference in the progression of dentin erosion to the different types of MMP inhibitors used, regardless of dentin condition (with or without DOM) and regardless of the type of fluoride used; (3) there is no difference in the progression of erosion between dentin, with or without MOD, regardless of the type of fluoride tested and treatment with MMP inhibitors. 

4 CONCLUSIONS 



\section{CONCLUSIONS}

Based on the results, it can be concluded that the presence of DOM is an extremely importante factor for the reduction of dentin erosion and the best treatment is the $\mathrm{TiF}_{4}$ varnish in vitro, regardless of the use of MMP inhibitors. 

REFERENCES 



\section{REFERENCES}

1- AGUIAR, Y. P. et al. Association between dental erosion and diet in Brazilian adolescents aged from 15 to 19: a population-based study. Scientific World Journal, v. 13, e818167, Feb 2014.

2- BALALAIE, A.; REZVANI, M. B.; MOHAMMADI BASIR, M. Dual function of proanthocyanidins as both MMP inhibitor and crosslinker in dentin biomodification: A literature review. Dent Mater, v. 37, n. 2, p. 173-182, 2018.

3- $\quad$ BARBOSA, C. S.; KATO, M. T.; BUZALAF, M. A. Effect of supplementation of soft drinks with green tea extract on their erosive potential against dentine. Aust Dent J, v. 56, n. 3, p. 317-321, 2011.

4- BEDRAN-RUSSO, A. K. et al. Changes in stiffness of demineralized dentin following application of collagen crosslinkers. J Biomed Mater Res B Appl Biomater, v. 86, n. 2, p. 330-334, Aug 2008.

5- BEDRAN-RUSSO, A. K. et al. Characterization of biomodified dentin matrices for potential preventive and reparative therapies. Acta Biomater, v. 7, n. 4, p. 1735-1741, Apr 2011.

6- BEDRAN-RUSSO, A. K. et al. Dentin biomodification: strategies, renewable resources and clinical applications. Dent Mater, v. 30, n. 1, p. 62-76, Jan 2014.

7- BOTEON, A. P. et al. Effect of different concentrations and application times of proanthocyanidin gels on dentin erosion. Am J Dent, v. 30, n. 2, p. 96-100, Apr 2017b.

8- BOTEON, A. P. et al., Effect of Proanthocyanidin-enriched extracts on the inhibition of wear and degradation of dentin demineralized organic matrix. Arch Oral Biol, v. 84, p. 118-124a.

9- BRACKETT, M. G. et al. Effect of Sodium Fluoride on the endogenous MMP Activity of Dentin Matrices. J Nat Sci, v. 1, n. 6, Jun 2015.

10- BUTler, W. T.; MUNKSGAARD, E. C.; RICHARDSON, W. S. Dentin proteins: chemistry, structure and biosynthesis. J Dent Res, v. 58, p. 817-824, Mar 1979.

11- BUZALAF, M. A.; CHARONE, S.; TJÄDERHANE L. Role of host-derived proteinases in dentine caries and erosion. Caries Res, v. 49, n. Suppl 1, p. 30-37, 2015. 
12- CASTELLAN, C. S. et al. Long-term stability of dentin matrix following treatment with various natural collagen cross-linkers. J Mech Behav Biomed Mater, v. 4, n. 7, p. 13431350 , Oct 2011.

13- CASTILHO, A. R. F. et al. Protective effect of experimental mouthrinses containing $\mathrm{NaF}$ and TiF4 on dentin erosive loss in vitro. J Appl Oral Sci, v. 23, n. 5, p. 486-490, Oct 2015.

14- COMAR, L. P. et al. Sound and Demineralised Enamel Treated with TiF4 in vitro: KOHSoluble Fluoride Deposition and SEM-EDXS Analysis. In: 60th Congress of the European Organisation for Caries Research. Caries Res, Liverpool, v. 47, p. 516, 2013.

15- COMAR, L. P. et al. TiF4 and NaF varnishes as anti-erosive agents on enamel and dentin erosion progression in vitro. J Appl Oral Sci, v. 23, n. 1, p. 14-18, Jan-Feb 2015.

16- EPASINGHE, D. J.; BURROW, M. F.; YIU, C. K. Y. Effect of proanthocyanidin on ultrastructure and mineralization of dentine collagen. Arch Oral Biol, v. 84, p. 29-36, Dec 2017.

17- FEMIANO F. et al. Dentin caries progression and the role of metalloproteinases: an update. Eur J Paediatr Dent, v. 17, n. 3, p. 243-247, Sep 2016.

18- FLURY, S. et al. The effect of a tin-containing fluoride mouth rinse on the bond between resin composite and erosively demineralised dentin. Clin Oral Investig, v. 17, n. 1, p. 217-225, Jan 2013.

19- GANSS C. et al. Efficacy of a tin/fluoride rinse: a randomized in situ trial on erosion. $\mathbf{J}$ Dent Res, v. 89, n. 11, p. 1214-1218, Nov 2010.

20- GANSS, C. et al. Effects of two fluoridation measures on erosion progression in human enamel and dentine in situ. Caries Res, v. 38, n. 6, p. 561-566, Nov-Dec 2004.

21- GANSS, C.; KLIMEK, J.; STARCK, C. Quantitative analysis of the impact of the organic matrix on the fluoride effect on erosion progression in human dentine using longitudinal microradiography. Arch Oral Biol, v. 49, n. 11, p. 931-935, Nov 2004.

22- GANSS, C.; SCHLUETER, N.; KLIMEK, J. Retention of KOH-soluble fluoride on enamel and dentine under erosive conditions - A comparison of in vitro and in situ results. Arch Oral Biol, v. 52, n. 1, p. 9-14, Jan 2007.

23- GANSS, C.; SCHULZE, K.; SCHLUETER, N. Toothpaste and erosion. Monogr Oral Sci, v. 23, p. 88-99, 2013. 
24- GENDRON, R. et al. Inhibition of the activities of matrix metalloproteinases 2, 8, and 9 by chlorhexidine. Clin Diagn Lab Immunol, v. 6, n. 3, p. 437-439, May 1999.

25- GU, Z.; LI, J.; SÖREMARK, R. Influence of tooth surface conditions on enamel fluoride uptake after topical application of TiF4 in vitro. Acta Odontol Scand, v. 54, n. 5, p. 279281, Oct 1996.

26- HAN, B. et al. Proanthocyanidin: a natural cross-linking reagent for stabilizing collagen matrices. J Biomed Mater Res A, v. 1, f. 65, n. 1, p. 118-124, Apr 2003.

27- HAN, B. et al. Proanthocyanidin: a natural cross-linking reagent for stabilizing collagen matrices, J Biomed Mater Res A, v. 65, n. 1, p. 118-24, 2003.

28- HIRAISHI, N. et al. In vitro evaluation of plant-derived agents to preserve dentin collagen. Dent Mater, v. 29, n. 10, p. 1048-1054, Oct 2013.

29- HOULLÉ, P. et al. High resolution electron microscopy: structure and growth mechanisms of human dentin crystals. J Dent Res, v. 76, n. 4, p. 895-904, Apr 1997.

30- HOVE, L. et al. The protective effect of TiF4, SnF2 and NaF on erosion of enamel by hydrochloric acid in vitro measured by white light interferometry. Caries Res, v. 40, n. 5, p. 440-443, 2006.

31- HOVE, L. H. et al. The protective effect of TiF4, SnF2 and NaF against erosion-like lesions in situ. Caries Res, v. 42, n. 1, p. 68-72, 2008.

32- KATO, M. T. et al. Activity of matrix metalloproteinases in bovine versus human dentine. Caries Res, v. 45, n. 5, p. 429-434, 2011.

33- KATO, M. T. et al. Effect of iron on matrix metalloproteinase inhibition and on the prevention of dentine erosion. Caries Res, v. 44, n. 3, p. 309-316, 2010 b.

34- KATO, M. T. et al. Gels containing MMP inhibitors prevent dental erosion in situ. J Dent Res, v. 89, n. 5, p. 468-472, 2010a.

35- KATO, M. T. et al. Impact of protease inhibitors on dentin matrix degradation by collagenase. J Dent Res, v. 91, n. 12, p. 1119-1123, Dec 2012.

36- KATO, M. T. et al. Protective effect of green tea on dentin erosion and abrasion. J Appl Oral Sci, v. 17, n. 6, p. 560-564, Nov-Dec 2009. 
37- KATO, M. T. et al. Sodium fluoride inhibits MMP-2 and MMP-9. J Dent Res, v. 93, n. 1, p. 74-77, Jan 2014.

38- KHADDAM, M. et al. Grape seed extracts inhibit dentin matrix degradation by MMP3. Front Physiol, v. 31, n. 5, p. 425, Oct 2014.

39- KIM, D. S. et al. The influence of chlorhexidine on the remineralization of demineralized dentine. J Dent, v. 39, n. 12, p. 855-862, Dec 2011.

40- LEVY F. M. et al. The erosion and abrasion-inhibiting effect of TiF(4) and NaF varnishes and solutions on enamel in vitro. Int J Paediatr Dent, v. 22, n. 1, p. 11-16, Jan 2012.

41- LIU, R. R. et al. Anti-proteolytic capacity and bonding durability of proanthocyanidinbiomodified demineralized dentin matrix. Int J Oral Sci, v. 6, n. 3, p. 168-174, Sep 2014.

42- LIU, Y. et al. Enhancement in dentin collagen's biological stability after proanthocyanidins treatment in clinically relevant time periods. Dent Mater, v. 29, n. 4, p. 485-492, Apr 2013.

43- LUSSI A. Erosive tooth wear - a multifactorial condition of growing concern and increasing knowledge. Monogr Oral Sci, v. 20, p. 1-8, 2006.

44- LUSSI, A.; CARVALHO, T. S. Erosive tooth wear: a multifactorial condition of growing concern and increasing knowledge. Monogr Oral Sci, v. 25, p. 1-15, 2014.

45- LUSSI, A.; CARVALHO, T. S. The future of fluorides and other protective agents in erosion prevention. Caries Res, v. 49, Suppl 1, p. 18-29, 2015.

46- MAGALHÃES A. C. et al. Synthesis and characterization of hydroxyapatite treated with TiF4 in vitro. In: 60th Congress of the European Organisation for Caries Research. Caries Res, Liverpool, v. 47, p. 515, 2013.

47- MAGAlHÃES, A. C. et al. Chlorhexidine and green tea extract reduce dentin erosion and abrasion in situ. J Dent, v. 37, n. 12, p. 994-998, Dec 2009.

48- MAGALHÃES, A. C. et al. Effect of a single application of TiF(4) and NaF varnishes and solutions on dentin erosion in vitro. J Dent, v. 38, p. 153-157, Feb 2010.

49- MAGALHÃES, A. C. et al. Effect of a single application of TiF4 varnish versus a daily use of low-concentrated $\mathrm{TiF} 4 / \mathrm{NaF}$ solution on tooth erosion prevention in vitro. Caries Res, v. 50, n. 5, p. 462-470, 2016. 
50- MAGAlHÃES, A. C. et al. Fluoride in dental erosion. Monogr Oral Sci, v. 22, p. 158170, 2011.

51- MAGALHÃES, A. C. et al. The effect of an experimental $4 \%$ TiF4 varnish compared to $\mathrm{NaF}$ varnishes and 4\% TiF4 solution on dental erosion in vitro. Caries Res, v. 42, n. 4, p. 269-274, 2008.

52- MARTINES DE SOUZA, B. et al. The Impact of the Demineralized Organic Matrix on the Effect of TiF4 Varnish on the Progression of Dentin Erosive Loss. Caries Res, v. 51, n. 3, p. 264-270, 2017.

53- MAZZONI A. et al. Immunohistochemical and biochemical assay of MMP-3 in human dentine. J Dent, v. 39, n. 3, p. 231-237, Mar 2011.

54- MAZZONI, A. et al. Zymographic analysis and characterization of MMP-2 and -9 forms in human sound dentin. J Dent Res, v. 86, n. 5, p. 436-440, May 2007. Erratum in: J Dent Res, v. 86, n. 8, p. 792, Aug 2007.

55- NAGPAL, R.; MANUJA, N.; PANDIT, I. K. Effect of proanthocyanidin treatment on the bonding effectiveness of adhesive restorations in pulp chamber. J Clin Pediatr Dent, v. 38, n. 1, p. 49-53, Fall 2013.

56- NANDAKUMAR M, NASIM I. Comparative evaluation of grape seed and cranberry extracts in preventing enamel erosion: An optical emission spectrometric analysis. $\mathbf{J}$ Conserv Dent, v. 21, n. 5, p. 516-520, 2018.

57- PAEPEGAEY, A. M. Measuring enamel erosion: a comparative study of contact profilometry, non-contact profilometry and confocal laser scanning microscopy. Dent Mater. v. 29, n. 12, p. 1265-1272, 2013.

58- PASHLEY, D. H. Clinical correlations of dentin structure and function. J Prosthet Dent, v. 66, n. 6, p. 777-781, Dec 1991.

59- PIERPOINT, W. S. o-Quinones formed in plant extracts. Their reactions with amino acids and peptides. Biochem J. v. 112, n. 5, p. 609-616, 1969.

60- RIBEIRO C. C.; GIBSON, I.; BARBOSA, M. A. The uptake of titanium ions by hydroxiapatite particles - structural changes and possible mechanisms. Biomaterials, $\mathrm{v}$. 27, n. 9, p. 1749-1761, Mar 2006. 
61- RUEL, G. et al. Plasma matrix metalloproteinase (MMP)-9 levels are reduced following low-calorie cranberry juice supplementation in men. J Am Coll Nutr, v. 28, n. 6, p. 694701, Dec 2009.

62- RUGG-GUNN, A. Dental caries: strategies to control this preventable disease, Acta Med Acad, v. 42, n. 2, p. 117-130, 2013.

63- SALAS, M. M. et al. Diet influenced tooth erosion prevalence in children and adolescents: Results of a meta-analysis and meta-regression. J Dent, v. 43, n. 8, p. 865875, Aug 2015b.

64- SALAS, M. M. et al. Estimated prevalence of erosive tooth wear in permanent teeth of children and adolescents: an epidemiological systematic review and meta-regression analysis. J Dent. v. 43, n. 1, p. 42-50, Jan 2015a.

65- SCHLUETER N. et al. Effect of pepsin on erosive tissue loss and the efficacy of fluoridation measures in dentine in vitro. Acta Odontol Scand, v. 65, n. 5, p. 298-305, Oct 2007.

66- SCHLUETER N. et al. Enzyme activities in the oral fluids of patients suffering from bulimia: a controlled clinical trial. Caries Res, v. 46, n. 2, p. 130-139, 2012.

67- SCHLUETER, N.; JUNG, K.; GANSS, C. Profilometric Quantification of Erosive Tissue Loss in Dentine: A Systematic Evaluation of the Method. Caries Res, p. 50, v. 5, p. 443454, 2016.

68- SESEOGULLARI-DIRIHAN, R. et al. Effect of pretreatment with collagen crosslinkers on dentin protease activity. Dent Mater, v. 31, n. 8, p. 941-947, Aug 2015.

69- SESEOGULLARI-DIRIHAN, R. et al. Use of crosslinkers to inactivate dentin MMPs. Dent Mater, v. 32, n. 3, p. 423-432, Mar 2016.

70- SOUZA, B. M. et al. Effect of experimental mouthrinses containing the combination of $\mathrm{NaF}$ and TiF4 on enamel erosive wear in vitro. Arch Oral Biol, v. 29;59, n. 6, p. 621624, Mar 2014.

71- SULKALA M. et al. Matrix metalloproteinase-8 (MMP-8) is the major collagenase in human dentin. Arch Oral Biol, v. 52, n. 2, p. 121-127, Feb 2007.

72- TEZEL, H.; ERGUCU, Z.; ONAL, B. Effects of topical fluoride agents on artificial enamel lesion formation in vitro. Quintessence Int, v. 33, n. 5, p. 347-352, May 2002. 
73- TJÄDERHANE, L. et al. Matrix metalloproteinases and other matrix proteinases in relation to cariology: the era of 'dentin degradomics', Caries Res. v. 49, n. 3, p. 193-208, 2015.

74- TJÄDERHANE, L. et al. Optimizing dentin bond durability: control of collagen degradation by matrix metalloproteinases and cysteine cathepsins. Dent Mater, v. 29, n. 1, p. 116-135, 2013.

75- TJÄDERHANE, L. et al. The activation and function of host matrix metalloproteinases in dentin matrix breakdown in caries lesions. J Dent Res, v. 77, n. 8, p. 1622-1629, Aug 1998.

76- VISSE, R.; NAGASE, H. Matrix metalloproteinases and tissue inhibitors of metalloproteinases: structure, function, and biochemistry. Circ Res, v. 92, n. 8, p. 827839, 2003.

77- WIEGAND, A.; ATTIN, T. Influence of fluoride on the prevention of erosive lesions a review. Oral Health Prev Dent, v. 1, n. 4, p. 245-253, 2003. 